\title{
Editorial
}

\section{O antigo e o novo: uma estranha perspectiva}

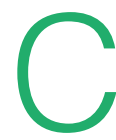

omemoraram-se, em 2018, os 40 anos da Sociedade Brasileira de Vácuo (SBV). Um marco para uma sociedade ativa, que vem proporcionando o compartilhamento do conhecimento, colaborando na formação de estudantes e técnicos, divulgando a aplicação da ciência e da tecnologia de vácuo ao longo de todo esse tempo.

É uma sociedade científica sem fins lucrativos, suportada por professores, pesquisadores, representantes e fabricantes de equipamentos de vácuo, além de agências de fomento. A SBV participa ativamente do cenário científico e tecnológico, nacional e internacional, além de promover cursos em várias áreas do conhecimento. A sociedade é membro da International Union for Vacuum Science, Technique and Applications (IUVSTA), da qual participa em conselhos técnicos e administrativos.

Em julho de 1978, a revista Química Nova indicava a formação da SBV, a pedido do Prof. Dr. Neelkantha ${ }^{a}$ que pertencia ao Departamento de Ciência dos Materiais do Instituto Militar de Engenharia; assim, a sociedade já nascia multidisciplinar. Medeiros', ao analisar a implantação da "ciência de base tecnológica" por meio da construção de aceleradores de partículas no país, ressalta a importância da tecnologia de vácuo para o desenvolvimento da indústria brasileira. Assim, na década de 1940, os físicos da Universidade de São Paulo (USP), devido ao seu conhecimento da tecnologia de vácuo, ajudaram os esforços de guerra "no recondicionamento das válvulas de potência dos transmissores de rádio" da Marinha; na década seguinte, o Instituto Tecnológico de Aeronáutica (ITA) ensinava aos engenheiros eletrônicos a tecnologia de vácuo e a construção de válvulas. Consequência direta dessa trajetória é a intensa interação empresa-universidade nos anos 1970, o que levou ao oferecimento de um curso inédito de tecnologia do vácuo, acessível.

"[...] tanto aos estudantes do terceiro ano do curso de Física da USP quanto aos técnicos dos mais diversos ramos industriais, desde empresas de grande porte como a Petrobras até segmentos industriais como o de faróis e lâmpadas. No total, foram quinhentas as empresas, todas usuárias da tecnologia do vácuo, que participaram deste curso rígido nos conceitos e com forte componente na parte experimental, no tocante a padrões envolvidos nas medidas em tecnologia do vácuo. Este curso também serviu de base, em 1978, para a primeira atividade promovida pela recém-criada Sociedade Brasileira do Vácuo."1

Ao analisar os artigos deste exemplar da revista, o último de 2018, encontra-se a consequência direta do trabalho desses pioneiros. Enquanto Cruz et al. apresentam todo o ciclo de construção de um equipamento de plasma totalmente baseado na tecnologia de vácuo, Santos et al. propõem a produção de novos catalisadores usando essa técnica. As novas frentes de desenvolvimento, como simulação e OLEDS, encontram-se igualmente presentes. Por fim, a comemoração não estaria completa se não fossem convidados trabalhos seminais, como o de Degasperi, sobre vazamento virtual, e de Ferreira et al., sobre produção de ambientes livres de partículas

Assim, ao finalizar o ano, e comemorar 40 anos da SBV, é possível perceber que o conhecimento proporcionado e, mais importante, as pessoas relacionadas à SBV atravessaram barreiras em diversas frentes, mudaram a face da ciência e da tecnologia no nosso país e ganharam o mundo. Parabéns a todos que pertenceram a essa história.

Maria Lúcia Pereira da Silva

Editora-chefe

\section{REFERÊNCIAS}

1. Medeiros TR de. A implantação da ciência de base tecnológica: um estudo do desenvolvimento da física experimental com aceleradores de partículas na Universidade de São Paulo (1934-1982) [tese]. Campinas (SP): Universidade Estadual de Campinas, Instituto de Geociências; 2012.

${ }^{a}$ Atualmente o Prof. Neelkanth G. Dhere (dhere@fsec.ucf.edu) encontra-se na University of Central Florida, no Florida Solar Energy Center (FSEC). 


\section{Editorial}

\section{Old and new: some Odd perspectives}

\footnotetext{
- his year it is celebrated the 40th anniversary of Brazilian Vacuum Society (SBV). A milestone for an assertive Society that has been granted the share of knowledge, cooperated on students and technicians formation and disseminated the application of Vacuum Science and Technology on all these years.
}

It is a non-profit scientific society, sponsored by professors, researchers, vacuum equipment representatives and manufactures, let alone research funding agencies. SBV actuates hardly on the scientific and technological scenery, internationally and in the country, and also provides courses on several distinct knowledge areas. SBV is affiliated to International Union for Vacuum Science, Technique and Applications (IUVSTA), actuating on Technical and administrative counsels.

On July 1978, Química Nova Journal, attending to a request from Professor Neelkanth G. Dhere ${ }^{a}$, who at that time belonged to the Materials Science Department of Instituto Militar de Engenharia, announced the formation of the Brazilian Vacuum Society; therefore, the society already was born with a multidisciplinary characteristic. Medeiros ${ }^{1}$ analyzed the implantation of technological science in the country through the development of particles accelerators and emphasized the importance of vacuum technology on the development of Brazilian industry. Thus, on the 1940s, USP physicists, due to the knowledge of such technology, helped the Navy war efforts "on the reconditioning of power valves from radio transmitters"; on the next decade, ITA taught the vacuum technology and the valve manufacturing to electronic engineering. A direct consequence of this trajectory is the intense interaction enterprise-university on the 1970s, which led to the offering of an unprecedented course on vacuum technology, open.

"not only to USP 3rd year physicist students but also to any technician on several industrial sectors, from large companies, such as Petrobras, to industrial segments, such as car headlights and incandescent lamps. In the end, five hundred enterprises, all vacuum technology dependent, attended this course that was rigid on concepts and highly experimental regarding vacuum standards measurements. This course also composed, in 1978, as the first activity promoted by the recently founded Brazilian Vacuum Society"1

Analyzing the papers presented on this issue, the last this year, it is possible to notice the direct consequence of the work of such pioneers. Whereas Cruz et al present the whole cycle of plasma equipment manufacturing, a device completed based on vacuum technology, Santos et al propose the production of new catalysts using this technique. New development frontiers, such as simulation an OLEDs, are also present. Finally, the commemoration would not be complete if seminar works were not invited, as Degasperi on virtual leaks and Ferreira et al on the manufacturing of particles free environments.

Therefore, on the end of this year, along with the commemoration of the 40th Brazilian Vacuum Society anniversary, it is possible to observe that the knowledge offered and, most important, people related to the SBV, crossed barriers on different frontiers, changed the face of the science and technology in this country and earned the world. Well done people, congratulations to everybody that belonged to this story.

\section{Maria Lúcia Pereira da Silva \\ Editor-in-chief}

\section{REFERENCES}

1. Medeiros TR de. A implantação da ciência de base tecnológica: um estudo do desenvolvimento da física experimental com aceleradores de partículas na Universidade de São Paulo (1934-1982) [tese]. Campinas (SP): Universidade Estadual de Campinas, Instituto de Geociências; 2012.

${ }^{a}$ Currently, Prof Neelkanth G. Dhere (dhere@fsec.ucf.edu) is at the University of Central Florida, no FSEC (Florida Solar Energy Center) 